Y. A. S. Anwar, ALCHEMY jurnal penelitian kimia, vol. 11 (2015), no. 1, hal. 29-37

\title{
PENGARUH PENAMBAHAN ENZIM TANASE TERHADAP SIFAT KIMIA SIRUP BUAH SEMU JAMBU METE (Anacardium occidentale Linn)
}

\section{(EFFECT OF TANNASE ON CHEMICAL PARAMETERS OF CASHEW APPLE JUICE (Anacardium occidentale Linn))}

\author{
Yunita Arian Sani Anwar \\ Program Studi Pendidikan Kimia, Fakultas Keguruan dan Ilmu Pendidikan, Universitas \\ Mataram Jl. Majapahit 62 Mataram, Indonesia \\ email: rian_bik@yahoo.com
}

Received 22 February 2014, Accepted 13 July 2014, Published 01 March 2015

\begin{abstract}
ABSTRAK
Sebelumnya telah dihasilkan enzim tanase dari Aspergillus niger menggunakan media padat. Pada penelitian ini, enzim tanase yang dihasilkan diaplikasikan pada sirup buah jambu mete. Penelitian ini bertujuan untuk mengetahui pengaruh penambahan enzim tanase terhadap sifat sirup buah jambu. Konsentrasi enzim yang digunakan divariasi 0; 0,$02 ; 0,04 ; 0,06 ; 0,08$ dan $0,1 \%(\mathrm{v} / \mathrm{v})$. Hasil yang diperoleh dibandingkan dengan sifat kimia sirup buah jambu mete yang diberi perlakuan dengan suhu tinggi $\left(100{ }^{\circ} \mathrm{C}\right)$. Hasil penelitian menunjukkan bahwa penambahan enzim tanase sebesar $0,1 \%(\mathrm{v} / \mathrm{v})$ memberikan hasil yang paling baik yaitu kandungan tanin yang lebih rendah jika dibandingkan dengan sirup yang diproduksi dengan penggunaan suhu tinggi. Penambahan enzim tanase pada sirup buah jambu mete tidak mempengaruhi kandungan vitamin $\mathrm{C}$, protein dan $\mathrm{pH}$. Penggunaan suhu tinggi menyebabkan penurunan kadar vitamin $\mathrm{C}$ dan protein secara signifikan.
\end{abstract}

Kata Kunci : Buah Semu Jambu Mete, Enzim Tanase, Tanin

\begin{abstract}
We previously produced tannase from Aspergillus niger using solid state medium. In the present study the enzyme used cashew apple juice. The aim this research was to know effect of tannase on chemical parameters of cashew apple juice. The concentration of tannase used was $0 ; 0.02 ; 0.04 ; 0.06 ; 0.08$ and $0.1 \%(\mathrm{v} / \mathrm{v})$. The chemical properties of the juice produced by enzymatic method were compared with the juiced produced through high temperature treatment $\left(100{ }^{\circ} \mathrm{C}\right)$. This research showed that the addition of $0.1 \%(\mathrm{v} / \mathrm{v})$ of tannase enzyme provide the best product according to the lower content of tannins than the content of tannins in the juice produced with high temperature treatment. The tannase treatment did not change the vitamin $\mathrm{C}$ content, content of protein and $\mathrm{pH}$. Meanwhile, high temperature treatment decreased the content of vitamin $\mathrm{C}$ and protein.
\end{abstract}

Key words: cashew apple juice, tannase enzyme, tannin 


\section{PENDAHULUAN}

Pemanfaatan jambu mete hingga saat ini masih terbatas pada bijinya yang diolah menjadi kacang mete. Buah jambu mete sendiri belum banyak dimanfaatkan bahkan tidak dimanfaatkan sama sekali. Setiap tahunnya limbah buah jambu mete menimbulkan permasalahan lingkungan yang cukup serius.

Penyebab utama buah jambu mete belum dimanfaatkan secara optimal karena tingginya kadar tanin sehingga menimbulkan rasa sepat jika dikonsumsi (Muljohardjo 1990). Sirup buah jambu mete yang pernah diproduksi kurang menarik perhatian konsumen akibat rasa sepat yang ditimbulkan oleh kehadiran tanin. Padahal kandungan gizi buah jambu mete sangat bagus yaitu mengandung riboflavin (vitamin B2), asam askorbat (vitamin C) dan kalsium serta senyawa aktif yang diketahui dapat mencegah penyakit kanker. Kandungan vitamin C pada buah jambu mete cukup tinggi mencapai 180$250 \mathrm{mg}$ per 100 gram bahan.

Penurunan kandungan tanin dapat dilakukan dengan penambahan enzim tanase. Enzim ini bekerja secara spesifik mendegradasi tanin membentuk asam galat dan glukosa. Enzim ini biasanya digunakan secara luas pada industri makanan maupun obat-obatan. Dalam industri makanan, tanase digunakan pada produk teh instan, menjernihkan bir dan jus buah serta mengurangi efek antinutrisi tanin pada makanan ternak. Untuk industri obatobatan, tanase berperan dalam produksi asam galat, yaitu senyawa yang digunakan untuk mensintesis propil galat dan trimetoprim secara kimia (Pinto et al., 2001). Masyarakat biasanya menggunakan suhu tinggi untuk menurunkan kandungan tannin sehingga berpotensi merusak nutrisi penting yang terdapat pada bahan makanan.

Penelitian yang dilakukan Hamacher et al. (2001) melaporkan bahwa spesies yang berasal dari genus Aspergillus dan Penicillium memiliki kemampuan paling baik untuk memproduksi enzim tanase. Purnama (2004) juga membuktikan bahwa Aspergillus niger yang diisolasi dari kulit buah kakao mampu menurunkan kandungan tanin yaitu sebesar $79,28 \%$.

Penelitian yang dilakukan oleh Anwar et al. (2007) telah menghasilkan enzim tanase pada media padat. Namun aktivitas enzim yang dihasilkan masih rendah. Salah satu faktor yang menyebabkan rendahnya aktivitas enzim adalah komposisi media yang kurang tepat. Penelitian Anwar dan Burhanuddin (2012) telah mampu menghasilkan tanase dengan aktivitas yang lebih tinggi dibandingkan penelitian sebelumnya. Hanya saja, aplikasi enzim ini untuk menurunkan kandungan tanin belum dilakukan. 
Penelitian ini bertujuan untuk mengetahui pengaruh penambahan enzim tanase terhadap sifat kimia sirup buah semu jambu mete meliputi kandungan tanin, vitamin $\mathrm{C}$, kadar glukosa, kadar protein dan $\mathrm{pH}$.

\section{METODE PENELITIAN}

\section{Bahan.}

Bahan-bahan yang diperlukan meliputi kapang Aspergillus niger yang diisolasi dari kulit buah kakao, Tween 80 (Merck), $\mathrm{NaNO}_{3}, \mathrm{KCl}, \mathrm{MgSO}_{4} \cdot 3 \mathrm{H}_{2} \mathrm{O}, \mathrm{FeSO}_{4} \cdot 7 \mathrm{H}_{2} \mathrm{O}$, $\mathrm{K}_{2} \mathrm{HPO}_{4} \cdot 3 \mathrm{H}_{2} \mathrm{O}$, asam tanat (Sigma), tepung gandum, glukosa, $\mathrm{NaOH}, \mathrm{HCl}$, Na-sitrat, asam sitrat, etanol 95\% (Merck), Coomasie Brilliant Blue G 250 (Merck), $\mathrm{H}_{3} \mathrm{PO}_{4} 85 \%$ (Merck), bovine serum albumin (Merck), $\left(\mathrm{NH}_{4}\right)_{2} \mathrm{SO}_{4}$ (Kanto), EDTA, $\mathrm{Na}_{2} \mathrm{CO}_{3}$, buah semu jambu mete, $\mathrm{KI}, \mathrm{I}_{2}$, amilum $1 \%$, besi (III) ammonium disulfat, kalium besi (III) sianida, anthrone (9,10-dihidro-9-oxanthrecene), $\mathrm{H}_{2} \mathrm{SO}_{4}$ pekat, glukosa.

Alat-alat yang digunakan dalam penelitian ini adalah pipet volumetrik, mikropipet, inkubator, Shaker bath, magnetik stirer, Sentrifuge dingin (Beckman J2-21), Water bath, spektrofotometer, selofan (Sigma), autoklaf, $\mathrm{pH}$ meter, neraca analitik, vortex, corong Buncher, vakum, laminar, Erlenmeyer, jarum ose, kertas Whatman no.1 (Advantec) dan peralatan gelas yang biasa digunakan dalam laboratorium.

\section{Metode.}

\section{Produksi Enzim Tanase.}

Prosedur untuk produksi tanase mengacu pada metode Sanchez (2003) dan Anwar and Burhanuddin (2012). Sebanyak $5 \mathrm{~g}$ tepung gandum dimasukkan ke dalam Erlenmeyer $125 \mathrm{~mL}$ dan dibasahi dengan $10 \mathrm{~mL}$ medium Czapeck yang mengandung $3 \mathrm{~g} / \mathrm{L} \mathrm{NaNO}_{3}$; 0,5 g/L KCl; 0,348 g/L MgSO $4.3 \mathrm{H}_{2} \mathrm{O} ; 0,01 \mathrm{~g} / \mathrm{L} \mathrm{FeSO} 4.7 \mathrm{H}_{2} \mathrm{O} ; 1,301 \mathrm{~g} / \mathrm{L} \mathrm{K}_{2} \mathrm{HPO}_{4} \cdot 3 \mathrm{H}_{2} \mathrm{O}$ pada $\mathrm{pH}$ 5,5. Media selanjutnya disterilisasi dengan menggunakan autoklaf pada suhu sebesar $121{ }^{\circ} \mathrm{C}$ selama 15 menit. Setelah itu, ke dalam media padat tersebut diinokulasikan $1 \mathrm{~mL}$ spora jamur dan diinkubasi pada suhu kamar selama 3 hari.

\section{Isolasi Enzim Kasar.}

Isolasi enzim kasar dilakukan dengan cara mengekstrak media fermenatsi dengan menambahkan $50 \mathrm{~mL}$ aquades steril yang mengandung 0,01\% Tween 80. campuran tersebut dilarutkan dengan menggunakan magnetik stirrer. Enzim kasar (crude enzyme) selanjutnya dipisahkan dari media melalui sentrifugasi. Supernatan disaring dengan kertas Whatman no. 1 dan dimasukkan ke dalam botol. 
Enzim kasar difraksinasi dengan amonium sulfat pada tingkat kejenuhan $70 \%$. Perlakuan ini dilakukan pada kondisi suhu $4{ }^{\circ} \mathrm{C}$ selama 3 jam. Pemisahan dilakukan dengan sentrifugasi 7700 rpm selama 20 menit pada suhu yang sama, kemudian endapan yang diperoleh disuspensikan dalam bufer sitrat $50 \mathrm{mM} \mathrm{pH} \mathrm{5,0.} \mathrm{pemekatan} \mathrm{enzim}$ dilakukan dengan cara dialisis pada suhu $4{ }^{\circ} \mathrm{C}$ selama semalam dan bufernya dapat diganti beberapa kali sampai cairan diluar selofan tidak bereaksi dengan larutan Nessler.

\section{Pembuatan Sirup.}

Pembuatan sirup jambu mete dilakukan dengan cara buah jambu mete diblender, kemudian diperas sehingga diperoleh sari buah jambu mete. Ke dalam filtrat ditambahkan enzim tanase dengan konsentrasi 0; 0,02;0,04;0,06; dan 0,08\% (v/v), didiamkan selama 1 jam pada suhu kamar. Filtrat dipanaskan selama 5 menit untuk inaktivasi enzim. Sebagai pembanding, filtrat jambu mete dipanaskan pada suhu $100{ }^{\circ} \mathrm{C}$ selama 20 menit dan ditambahkan gelatin untuk mengendapkan tanin. Perlakuan diulang sebanyak 3 kali.

\section{Pengujian Gula Pereduksi.}

Sebanyak 0,1\% anthrone (9,10-dihidro-9-oxanthracene) ditimbang dan dimasukkan ke dalam labu takar $250 \mathrm{~mL}$ serta ditambah $\mathrm{H}_{2} \mathrm{SO}_{4}$ pekat (dibuat dalam kondisi fresh). Larutan standar dibuat dengan melarutkan $200 \mathrm{mg}$ dalam $100 \mathrm{~mL}$ aquades. Sebanyak 10 $\mathrm{mL}$ larutan standar diencerkan hingga volume larutan $100 \mathrm{~mL}$.

Sebanyak $1 \mathrm{~mL}$ larutan standar glukosa atau sirup buah jambu mete dimasukkan ke dalam tabung reaksi. Tambahkan $10 \mathrm{~mL}$ aquades dan $5 \mathrm{~mL}$ reagen anthrone, diamkan dalam waterbath $\left(100{ }^{\circ} \mathrm{C}\right)$ selama 12 menit. Dinginkan larutan pada air mengalir dan ukur absorbansinya pada $\lambda=630 \mathrm{~nm}$.

\section{Penentuan Kadar Vitamin C.}

Sebanyak $10 \mathrm{~mL}$ sari buah ditambahkan 5 tetes amilum $1 \%$ dan ditambahkan 10 $\mathrm{mL}$ aquades. Kemudian dititrasi dengan larutan 0,01 $\mathrm{N}$ standar yodium sampai timbul

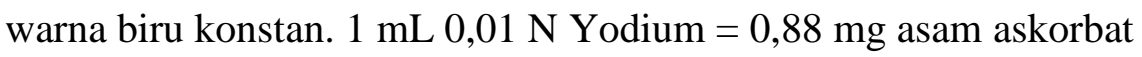

\section{Penentuan Kadar Tanin (Desmiaty et al., 2008).}

Larutan baku asam tanat $25 \mu \mathrm{g} / \mathrm{mL}$ dipipet masing-masing 1,0 $\mathrm{mL} ; 2,0 \mathrm{~mL} ; 4,0$ $\mathrm{mL}$; 5,0 mL; dan 6,0 mL ke dalam labu ukur $25 \mathrm{~mL}$. Masing-masing ditambah dengan 3,0 $\mathrm{mL}$ besi(III) amonium disulfat, diaduk selama 20 menit, ditambahkan $3 \mathrm{~mL}$ kalium besi (III) sianida, diaduk selama 20 menit kemudian ditambah aqua demineralisata hingga diperoleh seri larutan $1 ; 2 ; 4 ; 5$ dan $6 \mu \mathrm{g} / \mathrm{mL}$. Diukur serapan pada $720 \mathrm{~nm}$.

Sebanyak $5 \mathrm{~mL}$ sirup buah jambu mete ditambah aqua demineralisata hingga volume $10 \mathrm{~mL}$ kemudian diambil $1 \mathrm{~mL}$ dan dimasukkan ke dalam labu ukur $25 \mathrm{~mL}$ dan 
ditambah dengan 3,0 mL besi(III) amonium disulfat, diaduk selama 20 menit, ditambahkan $3 \mathrm{~mL}$ kalium besi (III) sianida, diaduk selama 20 menit. Tambahkan aquades hingga volume $25 \mathrm{~mL}$ dan serapannya diukur pada $720 \mathrm{~nm}$.

\section{Pengukuran Kadar Protein Sirup Buah Jambu Mete (Bradford, 1976).}

Pembuatan kurva standar protein BSA dengan metode Bradford dilakukan dengan melarutkan 100 mg BSA (Bovine Serum Albumin) dalam $25 \mathrm{~mL}$ aquades. Larutan tersebut kemudian diencerkan dengan aquades sampai $100 \mathrm{~mL}$. Setelah itu dibuat larutan standar protein dengan konsentrasi 10, 20, 30, 40, 50, 60, 70 dan $80 \mu \mathrm{g}$.

Masing-masing larutan standar dengan konsentrasi yang berbeda tersebut dipipet sebanyak $0,1 \mathrm{~mL}$ dan dimasukkan ke dalam tabung reaksi. Untuk blanko larutan standar diganti dengan 0,1 mL aquades. Sebanyak $5 \mathrm{~mL}$ pereaksi Bradford kemudian ditambahkan ke dalam larutan protein dan blanko. Selanjutnya divortex dan setelah 2 menit absorbansinya diukur dengan menggunakan spektrofotometer pada panjang gelombang $597 \mathrm{~nm}$.

Campuran 0,1 mL sirup dan $5 \mathrm{~mL}$ pereaksi Bradford dimasukkan ke dalam tabung reaksi. Setelah itu, campuran divortex dan setelah 2 menit diukur absorbansinya pada panjang gelombang $597 \mathrm{~nm}$. Nilai absorbansi yang diperoleh selanjutnya dikonversikan ke dalam kurva standar BSA untuk mendapatkan konsentrasi protein sirup buah jambu mete.

\section{HASIL DAN PEMBAHASAN}

Produksi enzim tanase menggunakan fermentasi media padat sesuai dengan penelitian Anwar \& Burhanuddin (2012). Aktivitas enzim tanase yang dihasilkan setelah melalui fraksinasi amonium sulfat adalah sebesar 18,33 U/mL. Jika dibandingkan dengan enzim kasar terjadi peningkatan aktivitas sebesar 8 kali.

Sifat kimia sirup buah jambu mete menunjukkan beberapa perubahan sebelum dan sesudah diberikan enzim tanase. Sifat kimia yang dimaksud meliputi kadar vitamin C, glukosa, tanin, protein dan $\mathrm{pH}$. Penambahan enzim tanase memberikan pengaruh yang nyata terhadap kadar glukosa dan tanin yang terdapat pada sirup buah jambu mete. Kadar glukosa cenderung mengalami kenaikan untuk semua perlakuan dengan enzim tanase. Namun, penggunaan suhu tinggi menyebabkan penurunan kadar glukosa (Tabel 1). Hasil uji Duncan $(\alpha=5 \%)$ menunjukkan penambahan enzim tanase sebesar 0,02 dan 0,04\% (v/v) tidak memberikan pengaruh yang signifikan terhadap kenaikan kadar glukosa. Penambahan enzim sebesar 0,06 hingga 0,1\% menunjukkan kenaikan yang signifikan dan kenaikan tertinggi ditunjukkan pada penambahan enzim sebesar $0,1 \%$. 
Tabel 1. Pengaruh penambahan enzim tanase terhadap kadar glukosa dan tanin sirup buah jambu mete

\begin{tabular}{lrr}
\hline Perlakuan & Kadar glukosa $(\%)$ & $\begin{array}{l}\text { Kadar tanin } \\
(\mathrm{mg} / 100 \mathrm{~g} \text { bahan })\end{array}$ \\
\hline Enzim 0\% & $13,23 \pm 0,54^{\mathrm{b}}$ & $2,30 \pm 0,67^{\mathrm{f}}$ \\
Enzim 0,02\% & $13,39 \pm 0,21^{\mathrm{b}}$ & $2,01 \pm 0,19^{\mathrm{e}}$ \\
Enzim 0,04\% & $14,00 \pm 0,17^{\mathrm{b}}$ & $1,87 \pm 0,15^{\mathrm{d}}$ \\
Enzim 0,06\% & $15,43 \pm 0,31^{\mathrm{c}}$ & $1,71 \pm 0,17^{\mathrm{c}}$ \\
Enzim 0,08\% & $16,52 \pm 0,18^{\mathrm{d}}$ & $1,60 \pm 0,53^{\mathrm{b}}$ \\
Enzim 0,1\% & $16,96 \pm 0,25^{\mathrm{e}}$ & $1,49 \pm 0,21^{\mathrm{a}}$ \\
Pemanasan & $12,07 \pm 0,14^{\mathrm{a}}$ & $1,89 \pm 0,10^{\mathrm{d}}$ \\
\hline
\end{tabular}

Angka-angka yang diikuti oleh huruf kecil yang sama pada kolom yang sama berbeda tidak nyata sesuai uji Duncan pada taraf $\alpha$ 5\%

Kadar tanin pada sirup buah jambu mete mengalami penurunan yang siginifikan setelah diberikan enzim tanase. Penambahan enzim tanase sebesar $0,1 \%$ menunjukkan penurunan kadar tanin yang lebih baik yaitu 1,49 mg/100 gram bahan. Jika dibandingkan dengan kontrol, terjadi penurunan kandungan tanin sebesar 35\%. Penggunaan suhu tinggi juga dapat menyebabkan berkurangnya kandungan tanin pada sirup buah jambu mete.

Tabel 2. Pengaruh penambahan enzim tanase terhadap kadar protein, vitamin $\mathrm{C}$ dan $\mathrm{pH}$ sirup buah jambu mete

\begin{tabular}{lrrr}
\hline Perlakuan & $\begin{array}{l}\text { Kadar protein } \\
(\mathrm{mg} / 100 \mathrm{~g} \text { bahan })\end{array}$ & $\begin{array}{l}\text { Vitamin C } \\
(\mathrm{mg} / 100 \mathrm{~g} \text { bahan })\end{array}$ & $\mathrm{pH}$ \\
\hline Enzim 0\% & $16,85 \pm 0,37^{\mathrm{b}}$ & $193,6 \pm 0,45^{\mathrm{c}}$ & $3,98 \pm 0,20^{\mathrm{a}}$ \\
Enzim 0,02\% & $16,79 \pm 0,21^{\mathrm{b}}$ & $170,1 \pm 0,19^{\mathrm{b}}$ & $3,81 \pm 0,15^{\mathrm{a}}$ \\
Enzim 0,04\% & $16,81 \pm 0,11^{\mathrm{b}}$ & $161,3 \pm 0,16^{\mathrm{b}}$ & $3,87 \pm 0,23^{\mathrm{a}}$ \\
Enzim 0,06\% & $16,72 \pm 0,10^{\mathrm{b}}$ & $167,2 \pm 0,01^{\mathrm{b}}$ & $3,85 \pm 0,18^{\mathrm{a}}$ \\
Enzim 0,08\% & $16,76 \pm 0,17^{\mathrm{b}}$ & $167,2 \pm 0,20^{\mathrm{b}}$ & $3,84 \pm 0,21^{\mathrm{a}}$ \\
Enzim 0,1\% & $17,05 \pm 0,24^{\mathrm{b}}$ & $167,2 \pm 0,20^{\mathrm{b}}$ & $3,79 \pm 0,16^{\mathrm{a}}$ \\
Pemanasan & $14,01 \pm 0,19^{\mathrm{a}}$ & $132 \pm 0,05^{\mathrm{a}}$ & $3,89 \pm 0,17^{\mathrm{a}}$ \\
\hline
\end{tabular}

Angka-angka yang diikuti oleh huruf kecil yang sama pada kolom yang sama berbeda tidak nyata sesuai uji Duncan pada taraf $\alpha 5 \%$

Berbeda dengan kadar glukosa dan tanin, hasil uji Duncan $(\alpha=5 \%)$ menunjukkan penambahan enzim tanase pada sirup buah jambu mete sepertinya tidak mempengaruhi kadar protein, vitamin $\mathrm{C}$ dan $\mathrm{pH}$ (Tabel 2). Namun penggunaan suhu tinggi mempengaruhi ketiga sifat kimia sirup buah jambu mete. Jika dibandingkan dengan kontrol, penggunaan suhu tinggi menurunkan kandungan protein dan vitamin $\mathrm{C}$ sirup.

Penurunan kandungan tanin pada sirup buah jambu mete disebabkan oleh reaksi hidrolisis enzim tanase. Enzim ini bekerja pada ikatan ester tanin terhidrolisis dan digunakan secara luas untuk menurunkan kandungan tanin (Belmares et al., 2004). Semakin besar konsentrasi enzim tanase yang digunakan, semakin besar penurunan 
kandungan tanin pada sirup buah jambu mete. Penggunaan suhu tinggi juga dapat menurunkan kandungan tanin. Suhu tinggi dapat mempercepat proses pemutusan ikatan ester pada tanin terhidrolisis (Hagerman, 2002).

Penambahan enzim tanase sebesar $0,06 \% ; 0,08 \%$ dan $0,1 \%$ meningkatkan kadar glukosa pada sirup buah jambu mete. Hal ini disebabkan oleh kerja enzim tanase yang dapat menghidrolisis tanin terhidrolisis membentuk asam galat dan glukosa (Hagerman, 2002). Selain itu, kandungan flavonol terglikosilasi yang terdapat pada sirup buah jambu mete mengandung ikatan ester yang dapat dihidrolisis oleh enzim tanase menghasilkan glukosa (de Brito et al., 2007).

Penambahan enzim tanase pada sirup buah jambu mete tidak mempengaruhi kandungan vitamin $\mathrm{C}$, protein dan $\mathrm{pH}$. Penelitian Rout and Banerjee (2006) telah memproduksi enzim tanase dari Aspergillus oryzae dengan aktivitas dan karakter yang berbeda dengan enzim tanase pada penelitian ini. Aplikasi enzim tanase tersebut juga melaporkan tidak terjadi perubahan kadar vitamin $\mathrm{C}$ yang signifikan pada jus buah jambu mete dan jus pomegranate yang diberi pelakuan dengan enzim tanase. Demikian pula halnya dengan kandungan protein yang diberi perlakuan dengan enzim tanase pada kedua jus. Namun, penggunaan suhu tinggi menyebabkan penurunan kadar vitamin $\mathrm{C}$ dan protein. Seperti yang diungkapkan oleh de Man (1999) penggunaan suhu tinggi dapat merusak vitamin C. Protein juga mudah mengalami denaturasi pada suhu tinggi yang dapat mengurangi kandungannya di dalam bahan makanan (Belitz et al., 2009). Penelitian ini menunjukkan bahwa penggunaan enzim tanase dapat mengurangi kandungan tanin tanpa merusak nutrisi penting seperti vitamin $\mathrm{C}$ yang terdapat pada sirup buah jambu mete.

Jika dilihat dari tampilan, sirup buah jambu mete yang diberikan enzim terlihat lebih jernih dibandingkan kontrol. Penurunan kandungan tanin sebanding dengan warna jus buah yang lebih jernih. Talasila et al. (2011) mengungkapkan bahwa tanin yang terdapat pada jus buah jambu mete dapat menimbulkan warna kegelapan pada jus buah dan penambahan metabisulfit dapat mengurangi warna coklat pada jus akibat dari menurunnya kadar tanin. Lebih lanjut, Belmares et al. (2004) mengungkapkan bahwa enzim tanase dapat digunakan untuk menjernihkan beer dan sari buah.

\section{KESIMPULAN}

Penambahan enzim tanase pada sirup buah jambu mete secara signifikan mampu menurunkan kandungan tannin dan meningkatkan kadar glukosa sirup. Konsentrasi enzim tanase sebesar $0,1 \%$ memberikan hasil yang lebih baik jika dilihat dari penurunan kadar 
tanin. Hasil analisis vitamin $\mathrm{C}$, protein dan $\mathrm{pH}$ tidak mengalami perubahan pada sirup buah jambu mete yang diberi perlakuan dengan enzim tanase. Namun, perlakuan dengan suhu tinggi menyebabkan penurunan kadar vitamin $\mathrm{C}$ dan protein secara signifikan.

\section{DAFTAR PUSTAKA}

Anwar, Y.A.S. and Burhanuddin, 2012, Pengaruh Komposisi Media Terhadap Aktivitas dan Karakter Enzim Tanin Acyl Hidrolase dari Aspergillus niger, Jurnal Ilmu Kefarmasian Indonesia, vol. 10, no. 2, pp. 87-92.

Anwar, Y.A.S., Hasim, and Artika, I.M, (2007), The Production of Tannin Acyl Hydrolase from Aspergillus niger, Mikrobiologi Indonesia, vol. 1, no. 2, pp. 91-94.

Belitz H.D, W. Grosch, P. Schieberle, (2009), Food Chemistry, edisi 4. Springer-Verlag, Berlin, pp. 40-56.

Belmares, R., Carlos, J., Esquivel, C., Harrera, R.R, Coronel, A.R., and Aguilar, C.N., 2004, Microbial Production of Tannase: An enzyme with Potential Use in Food Industry, Food Science and Technology, vol. 37, pp. 857-864, DOI: $10.1016 /$ j.lwt.2004.04.002.

Bradford, M.M., 1976, A Rapid and Sensitive Method for The Quantitation of Microgram Quantities of Protein Utilizing The Principle of Protein Dye Binding, Analytical Biochemistry, vol. 72, pp. 248-254.

de Brito, S.E., Pessanha de Araujo C.P, Lin L-Z, and Harnly, J., (2007), Determination of the flavonoid components of cashew apple (Anacardium occidentale) by LC-DADESI/MS, Food Chemistry, vol. 105, pp. 1112-1118.

de Man J.M., (1999), Principles of Food Chemistry, $3^{\text {th }}$ ed., Aspen Publisher, Inc., Maryland, pp. 366-372.

Hagerman, A.E., (2002), Tannin Chemistry, diakses pada 9 Juli 2012 (http://www.users.muohio .edu/ hagermae / tanin.pdf)..

Hamacher, M.S., Terzi, S.C., and Couri S., 2001, Increase of tannase production in solid state fermentation by Aspergillus niger 3T5B8, diakses pada 8 Juli 2012 ( http://www.nrel.gov/ biotechsymp 25/docs/abst 3-68.doc).

Muljohardjo, M., (1990), Jambu Mete dan Teknologi Pengolahannya (Anacardium occidentale L), Yogyakarta, Liberty, pp. 187-188.

Pinto, G.A.S., Leite, S.G.F., Terzi, S.C., and Couri S., 2001, Selection of Tannase Producing Aspergillus niger Strains, Brazilian Journal of Microbiology, vol. 32, pp. 24-26.

Purnama, I.N., (2004), Kajian potensi isolat kapang pemecah ikatan tanin pada kulit buah kakao (Thebroma cacao L), Skripsi, Institut Pertanian Bogor, Bogor, Indonesia.

Rout S. and Banerjee, R., (2006), Production of tannase under mSSF and its aplication in fruit juice debittering, Indian Journal of Biotechnology,vol. 5, pp. 346-350.

Sanchez, H.H., 2003, Optimization of Aspergillus niger tannase production using Taguchi methods, diakses pada 8 Juli 2005 (http://ift.confex.com/ift/ 2003/ techprogram/paper_19929.htm). . 
Y. A. S. Anwar, ALCHEMY jurnal penelitian kimia, vol. 11 (2015), no. 1, hal. 29-37

Talasila U, Vechalapu R.R, and Shaik K.B, 2011, Preservation and Shelf Life of Cashew Apple Juice, Internet Journal of Food Safety, vol. 13, pp. 275-280. 